\title{
Flavonoids from Machilus japonica Stems and Their Inhibitory Effects on LDL Oxidation
}

\author{
Se-Jin Joo ${ }^{1}$, Hee-Jung Park ${ }^{2}$, Ji-Hae Park ${ }^{2}$, Jin-Gyeong Cho ${ }^{2}$, Ji-Hyun Kang ${ }^{3}$, \\ Tae-Sook Jeong ${ }^{3}$, Hee Cheol Kang ${ }^{4}$, Dae-Young Lee ${ }^{5}$, Hack-Soo Kim ${ }^{1}$, Sang-Yo Byun ${ }^{6}$ \\ and Nam-In Baek ${ }^{2, *}$
}

1 R\&D Center, Seoul Cosmetics Co., Ltd., Incheon 443-749, Korea;

E-Mails: skincare@seoulcos.co.kr (S.-J.J.); hskim@seoulcos.co.kr (H.-S.K.)

2 Laboratory of Natural Products Chemistry, Graduate School of Oriental Medicinal Materials Biotechnology, Kyung Hee University, Yongin 446-701, Korea;

E-Mails: bluedew011@hanmail.net (H.-J.P.); wlgo3411@hanmail.net (J.-H.P.);

kukuku1555@khu.ac.kr (J.-G.J.)

3 National Research Laboratory of Lipid Metabolism \& Atherosclerosis, KRIBB,

Daejeon 305-806, Korea; E-Mails: bsloaucl@naver.com (J.-H.K.); tsjeong@kribb.re.kr (T.-S.J.)

4 Research \& Development Center, GFC Co., Ltd., Suwon 443-813, Korea;

E-Mail: cmkorea@unitel.co.kr

5 Department of Herbal Crop Research, National Institute of Horticultural and Herbal Science, RDA, Eumseong 369-873, Korea; E-Mail: dylee0809@korea.kr

6 Cosmetic Business R\&D Service Center, Graduate School, Ajou University, Suwon 443-749, Korea; E-Mail: sybyun@ajou.ac.kr

* Author to whom correspondence should be addressed; E-Mail: nibaek@khu.ac.kr; Tel.: +82-31-201-2661.

Received: 21 July 2014; in revised form: 16 August 2014 / Accepted: 27 August 2014 / Published: 16 September 2014

Abstract: Stems of Machilus japonica were extracted with $80 \%$ aqueous methanol $(\mathrm{MeOH})$ and the concentrated extract was successively extracted with ethyl acetate (EtOAc), normal butanol $(n-\mathrm{BuOH})$, and water. Six flavonoids were isolated from the EtOAc fraction: (+)-taxifolin, afzelin, (-)-epicatechin, 5,3'-di-O-methyl-(-)-epicatechin, 5,7,3'-tri- $O$-methyl-(-)-epicatechin, and 5,7-di-O-methyl-3',4'-methylenedioxyflavan-3-ol. The chemical structures were identified using spectroscopic data including NMR, mass spectrometry and infrared spectroscopy. This is the first report of isolation of these six compounds from M. japonica. The compounds were evaluated for their diphenyl picryl 
hydrazinyl scavenging activity and inhibitory effects on low-density lipoprotein oxidation. Compounds 1 and 3-6 exhibited DPPH antioxidant activity equivalent with that of ascorbic acid, with half maximal inhibitory concentration ( $\mathrm{IC}_{50}$ ) values of $0.16,0.21,0.17,0.15$ and $0.07 \mathrm{mM}$, respectively. The activity of compound 1 was similar to the positive control butylated hydroxytoluene, which had an $\mathrm{IC}_{50}$ value of $1.9 \mu \mathrm{M}$, while compounds 3 and $\mathbf{5}$ showed little activity. Compounds $\mathbf{1}, \mathbf{3}$, and $\mathbf{5}$ exhibited LDL antioxidant activity with $\mathrm{IC}_{50}$ values of $2.8,7.1$, and $4.6 \mu \mathrm{M}$, respectively.

Keywords: diphenyl picryl hydrazinyl; low-density lipoprotein-oxidation; flavonoid; Machilus japonica; NMR

\section{Introduction}

The family Lauraceae includes about 32 genera and 2500 species that are distributed in tropical and subtropical regions, especially in Southeast Asia [1]. In Korea, members of the Lauraceae family are found in the southern regions and in Jeju Island. In this study, we describe the chemical constituents and activity of Machilus japonica extracts. M. japonica is an evergreen tree with yellow-green flowers and oval leaves. A few studies on the chemical composition of this plant have resulted in the identification of lignans [2] and terpene compounds [3]. In addition, the biological activities of M. japonica extracts such as insecticidal activity [4], elastase inhibition activity [5], and inhibition of matrix metalloproteinase-9 activity [6] have been investigated; however, all of these activities have been identified from extracts of $M$. japonica leaves. Taking a different approach, the aim of this study was to explore the active components of the stem of $M$. japonica and to screen their biological activities.

A total of six flavonoids were isolated and identified from the stem of $M$. japonica. Because many flavonoids have been reported to exhibit antioxidant activities [7], the isolated flavonoids were also evaluated for DPPH radical scavenging activity. low-density lipoprotein (LDL) is susceptible to oxidative damage, and oxidized LDL (oxLDL) plays a key role in the development of atherosclerotic lesions [8]. oxLDL in vessel walls is subjected to rapid uptake by scavenger receptors on monocyte derived macrophages, leading to the formation of foam cells that accumulate cholesterol [9]. Thus, we also evaluated the isolated compounds for their ability to inhibit LDL oxidation. Our results suggest that extracts of M. japonica stems and the specific flavonoids found in these extracts may prove useful for preventing or treating hypercholesterolemia and atherosclerosis.

\section{Results and Discussion}

\subsection{Isolation and Structure Elucidation}

When the methanol extracts of $M$. japonica stem were resolved on silica gel thin layer chromatograms (TLC), some spots showed UV absorption and yellow colorization when sprayed with $10 \% \mathrm{H}_{2} \mathrm{SO}_{4}$ solution and heating, indicating the presence of flavonoids in the extracts. The methanol extract was fractionated into EtOAc, $n-\mathrm{BuOH}$, and $\mathrm{H}_{2} \mathrm{O}$ layers through solvent fractionation. Repeated silica gel and ODS c.c. of the EtOAc fraction yielded six purified compounds. The chemical structures 
of the compounds were determined by ${ }^{1} \mathrm{H}-\mathrm{NMR},{ }^{13} \mathrm{C}-\mathrm{NMR}$, distortionless enhancement by polarization transfer (DEPT), gradient correlation spectroscopy (gCOSY), gradient heteronuclear single-quantum coherence (gHSQC), and gradient heteronuclear multiple-bond connectivity (gHMBC) analysis as well as IR and MS spectroscopic data. Compounds 1-6 were identified as (+)-taxifolin (1), afzelin (2), (-)-epicatechin (3), 5,3'-di- $O$-methyl-(-)-epicatechin (4), 5,7,3'-tri- $O$-methyl-(-)-epicatechin (5), and 5,7-di-O-methyl-3',4'-methylenedioxyflavan-3-ol (6) based on physical and spectroscopic evidence and confirmed through comparison with published data (Figure 1).

Figure 1. Chemical structures of the six flavonoids isolated from the stem of M. japonica.<smiles>O=C1c2c(O)cc(O)cc2O[C@H](c2ccc(O)c(O)c2)[C@H]1O</smiles><smiles></smiles><smiles>[R6]Oc1cc(O)c2c(c1)O[C@H](c1ccc(O)c(OC)c1)[C@@H](O)C2</smiles>

(-)-epicatechin (3)

$\mathrm{R}_{1}=\mathrm{R}_{2}=\mathrm{R}_{3}=\mathrm{H}$<smiles>COc1cc(OC)c2c(c1)O[C@H](c1ccc3c(c1)OCO3)[C@H](O)C2</smiles>

5,7-di- $O$-methyl-3'4'methylenedioxyflavan-3-ol (6)

5,3'-di-O-methyl-(-)-epicatechin (4)

$\mathrm{R}_{1}=\mathrm{R}_{3}=\mathrm{CH}_{3}, \mathrm{R}_{2}=\mathrm{H}$

5,7,3'-tri- $O$-methyl-(-)-epicatechin (5)

$\mathrm{R}_{1}=\mathrm{R}_{2}=\mathrm{R}_{3}=\mathrm{CH}_{3}$

Compound 1 was isolated as a yellow amorphous powder and showed IR absorbance bands for hydroxyl $\left(3420 \mathrm{~cm}^{-1}\right)$, conjugated ketone $\left(1620 \mathrm{~cm}^{-1}\right)$, and aromatic $\left(1520 \mathrm{~cm}^{-1}\right)$ groups. The molecular weight was determined to be $304 \mathrm{~g} / \mathrm{mol}$ based on the pseudomolecular ion peak $\mathrm{m} / \mathrm{z} 305[\mathrm{M}+\mathrm{H}]^{+}$ in the positive FAB/MS spectrum. The ${ }^{1} \mathrm{H}-\mathrm{NMR}$ spectrum exhibited three olefin proton signals of a 1,2,4-trisubstituted benzene ring at $\delta_{\mathrm{H}} 6.95(1 \mathrm{H}, \mathrm{d}, J=2.0 \mathrm{~Hz}), \delta_{\mathrm{H}} 6.83(1 \mathrm{H}, \mathrm{dd}, J=8.0,2.0 \mathrm{~Hz})$, and $\delta_{\mathrm{H}} 6.79(1 \mathrm{H}, \mathrm{d}, J=8.0 \mathrm{~Hz})$ and two olefin methine proton signals of a 1,2,3,5-tetrasubstituted benzene ring at $\delta_{\mathrm{H}} 5.90(1 \mathrm{H}, \mathrm{d}, J=2.0 \mathrm{~Hz})$ and $\delta_{\mathrm{H}} 5.86(1 \mathrm{H}, \mathrm{d}, J=2.0 \mathrm{~Hz})$. Two oxygenated methine proton signals at $\delta_{\mathrm{H}} 4.89(1 \mathrm{H}, \mathrm{d}, J=11.6 \mathrm{~Hz})$ and $\delta_{\mathrm{H}} 4.49(1 \mathrm{H}, \mathrm{d}, J=11.6 \mathrm{~Hz})$, which were coupled with each other, were observed. From the $J$ value $(11.6 \mathrm{~Hz})$ between the two oxygenated methine proton signals, compound 1 was deduced to be a 2,3-trans configured flavanol. In the ${ }^{13} \mathrm{C}$-NMR spectrum, there were 15 carbon signals including one ketone signal at $\delta_{\mathrm{C}} 198.1$ (C-4). The twelve carbon signals were due to two benzene rings composed of five oxygenated olefin quaternary carbon signals at $\delta_{\mathrm{C}} 168.5(\mathrm{C}-7)$, 
$\delta_{\mathrm{C}} 165.1(\mathrm{C}-5), \delta_{\mathrm{C}} 164.2(\mathrm{C}-8 \mathrm{a}), \delta_{\mathrm{C}} 146.9\left(\mathrm{C}-4^{\prime}\right)$, and $\delta_{\mathrm{C}} 146.1\left(\mathrm{C}-3^{\prime}\right)$, two olefin quaternary carbon signals at $\delta_{\mathrm{C}} 129.6\left(\mathrm{C}-1^{\prime}\right)$ and $\delta_{\mathrm{c}} 100.4(\mathrm{C}-4 \mathrm{a})$, and five olefin methine carbon signals at $\delta_{\mathrm{C}} 120.7\left(\mathrm{C}-6^{\prime}\right)$, $\delta_{\mathrm{C}} 115.9\left(\mathrm{C}-2^{\prime}\right), \delta_{\mathrm{C}} 115.7\left(\mathrm{C}-5^{\prime}\right), \delta_{\mathrm{C}} 97.2(\mathrm{C}-6)$, and $\delta_{\mathrm{C}} 96.1$ (C-8). The multiplicity of each carbon was determined by DEPT. Two oxygenated methine carbon signals at $\delta \mathrm{C} 85.0(\mathrm{C}-2)$ and $\delta_{\mathrm{C}} 73.5(\mathrm{C}-3)$ were also observed. The combination of ${ }^{1} \mathrm{H},{ }^{13} \mathrm{C}-\mathrm{NMR}$, and specific rotation $\left(+41.0^{\circ}\right)$ data led to the conclusion that compound 1 was $(2 R, 3 R)-5,7,3$ ',4'-tetrahydroxyflavanonol, $(+)$-taxifolin $[10,11]$.

Compound 2 was isolated as a yellow amorphous powder and showed IR absorbance bands for hydroxyl $\left(3280 \mathrm{~cm}^{-1}\right)$, conjugated ketone $\left(1655 \mathrm{~cm}^{-1}\right)$, and aromatic $\left(1615 \mathrm{~cm}^{-1}\right)$ groups. The molecular weight was determined to be $432 \mathrm{~g} / \mathrm{mol}$ based on the pseudomolecular ion peak $\mathrm{m} / \mathrm{z} 431[\mathrm{M}-\mathrm{H}]^{-}$ in the negative ESI/MS spectrum. In the ${ }^{1} \mathrm{H}-\mathrm{NMR}$ spectrum, compound $\mathbf{2}$ showed proton signals of a para-disubstituted benzene ring at $\delta_{\mathrm{H}} 7.75(2 \mathrm{H}$, br. d, $J=8.8 \mathrm{~Hz})$ assigned for $\mathrm{H}-2^{\prime}, 6^{\prime}$ and $\delta_{\mathrm{H}} 6.92(2 \mathrm{H}$, br. d, $J=8.8 \mathrm{~Hz})$ assigned for $\mathrm{H}-3^{\prime}, 5^{\prime}$, and one 1,2,3,5-tetrasubstituted benzene ring at $\delta_{\mathrm{H}} 6.37(1 \mathrm{H}, \mathrm{d}$, $J=2.0 \mathrm{~Hz})$ and $\delta_{\mathrm{H}} 6.19(1 \mathrm{H}, \mathrm{d}, J=2.0 \mathrm{~Hz})$. In addition, there was one doublet hemiacetal proton signal at $\delta_{\mathrm{H}} 5.36$ with a coupling constant of $1.6 \mathrm{~Hz}$, one oxygenated proton signal at $\delta_{\mathrm{H}} 4.21(1 \mathrm{H}$, dd, $J=2.8,1.6 \mathrm{~Hz}$ ) along with additional oxygenated methine proton signals in the region from $\delta_{\mathrm{H}} 3.93$ to $\delta 3.68$, and one methyl proton signal $\delta_{\mathrm{H}} 0.91(3 \mathrm{H}, \mathrm{d}, J=5.6 \mathrm{~Hz})$ in the upfield shift, indicating the presence of a 6-deoxysugar. The ${ }^{13} \mathrm{C}-\mathrm{NMR}$ spectrum showed 21 carbon signals indicating that compound 2 was a flavonoid monoglycoside. The carbon signals observed included one ketone signal at $\delta_{\mathrm{C}} 178.0$ (C-4), six oxygenated olefin quaternary signals at $\delta_{\mathrm{C}} 164.3$ (C-5), $\delta_{\mathrm{C}} 161.1$ (C-4a), $\delta_{\mathrm{C}} 160.0$ (C-4'), $\delta_{\mathrm{C}} 157.2(\mathrm{C}-2), \delta_{\mathrm{C}} 157.0(\mathrm{C}-7)$, and $\delta_{\mathrm{C}} 134.6(\mathrm{C}-3)$, two olefin quaternary signals at $\delta_{\mathrm{C}} 121.1\left(\mathrm{C}-1^{\prime}\right)$ and $\delta_{\mathrm{C}} 108.4(\mathrm{C}-8 \mathrm{a})$, and six olefin methine signals at $\delta_{\mathrm{C}} 130.4\left(\mathrm{C}-2^{\prime}, 6^{\prime}\right), \delta_{\mathrm{C}} 115.0\left(\mathrm{C}-3^{\prime}, 5^{\prime}\right), \delta_{\mathrm{C}} 98.4(\mathrm{C}-6)$, and $\delta_{\mathrm{C}} 93.3(\mathrm{C}-8)$. The chemical shift and multiplicity data led us to determine that compounds 2 was a trihydroxyflavonol glycoside with a deoxyhexose moiety. The carbon resonance due to the 6-deoxysugar moiety including an anomer carbon signal at $\delta_{\mathrm{C}} 102.0(\mathrm{C}-1 ")$, four oxygenated methine carbon signals at $\delta_{\mathrm{C}} 71.7(\mathrm{C}-4 "), \delta_{\mathrm{C}} 70.7(\mathrm{C}-3 "), \delta_{\mathrm{C}} 70.6(\mathrm{C}-5 ")$, and $\delta_{\mathrm{C}} 70.5$ (C-2"), and one methyl carbon signal at $\delta_{\mathrm{C}} 16.3$ (C-6") indicated that the sugar was L-rhamnopyranose. The configuration of the anomer carbon was determined to be $\alpha$ based on the coupling constant of the anomer proton signal $(J=1.6 \mathrm{~Hz})$ in the ${ }^{1} \mathrm{H}-\mathrm{NMR}$ spectrum and the chemical shift of the anomer carbon signal $\left(\delta_{\mathrm{C}} 102.0\right)$ in the ${ }^{13} \mathrm{C}-\mathrm{NMR}$ spectrum. To determine the position of the $\alpha$-L-rhamnopyranosyl moiety, a gHMBC experiment was conducted. The gHMBC spectrum showed that the anomer proton signal $\left(\delta_{\mathrm{H}} 5.36, \mathrm{H}-1 "\right)$ was correlated with the oxygenated olefin quaternary carbon signal $\left(\delta_{c} 134.6, C-3\right)$, suggesting the presence of a glycosidic bond at C-3. Based on comparison of these data with those in the reported literature [12,13], compound 2 was identified as kaempferol-3- $O$ - $\alpha$-L-rhamnopyranoside, also known as afzelin.

Compound $\mathbf{3}$ was isolated as a yellow amorphous powder and showed IR absorbance bands for hydroxyl $\left(3450 \mathrm{~cm}^{-1}\right)$ and aromatic $\left(1624 \mathrm{~cm}^{-1}\right)$ groups. The molecular weight was determined to be $290 \mathrm{~g} / \mathrm{mol}$ based on the molecular ion peak $\mathrm{m} / z 290[\mathrm{M}]^{+}$in the EI/MS spectrum. The ${ }^{1} \mathrm{H}-\mathrm{NMR}$ spectrum showed three olefin methine proton signals at $\delta_{\mathrm{H}} 6.96(1 \mathrm{H}, \mathrm{d}, J=1.6 \mathrm{~Hz}), \delta_{\mathrm{H}} 6.78(1 \mathrm{H}, \mathrm{dd}$, $J=8.0,1.6 \mathrm{~Hz})$, and $\delta_{\mathrm{H}} 6.75(1 \mathrm{H}, \mathrm{d}, J=8.0 \mathrm{~Hz})$ due to a 1,2,4-trisubstituted benzene ring, and two olefin methine proton signals at $\delta_{\mathrm{H}} 5.93(1 \mathrm{H}, \mathrm{d}, J=1.6 \mathrm{~Hz})$ and $\delta \mathrm{H} 5.91(1 \mathrm{H}, \mathrm{d}, J=1.6 \mathrm{~Hz})$ due to a 1,2,3,5-tetrasubstituted benzene ring. Two oxygenated methine proton signals at $\delta_{\mathrm{H}} 4.80(1 \mathrm{H}$, br. s) and $\delta_{\mathrm{H}} 4.16(1 \mathrm{H}, \mathrm{m})$ and one methylene proton signal at $\delta_{\mathrm{H}} 2.85(1 \mathrm{H}, \mathrm{dd}, J=16.8,4.8 \mathrm{~Hz})$ and $\delta_{\mathrm{H}} 2.73$ $(1 \mathrm{H}, \mathrm{dd}, J=16.8,2.8 \mathrm{~Hz})$ were detected in the upfield shift. Coupling patterns of the oxygenated 
methine protons of the broad singlet and multiplet led us to assume that compound $\mathbf{3}$ was a 2,3-cis configured flavan-3-ol. A total of 15 carbon signals were observed in the ${ }^{13} \mathrm{C}-\mathrm{NMR}$ spectrum. From the downfield shift, 12 carbon signals of two benzene rings were observed; five oxygenated olefin quaternary signals at $\delta_{\mathrm{C}} 157.9$ (C-5), $\delta_{\mathrm{C}} 157.5$ (C-7), $\delta_{\mathrm{C}} 157.3$ (C-8a), $\delta_{\mathrm{C}} 145.8$ (C-4'), and $\delta_{\mathrm{c}} 145.7\left(\mathrm{C}-3^{\prime}\right)$, two olefin quaternary signals at $\delta_{\mathrm{C}} 132.2\left(\mathrm{C}-1^{\prime}\right)$ and $\delta_{\mathrm{C}} 100.0(\mathrm{C}-4 \mathrm{a})$, and five olefin methine signals at $\delta_{\mathrm{C}} 119.3\left(\mathrm{C}^{-} 6^{\prime}\right), \delta_{\mathrm{C}} 115.8\left(\mathrm{C}-5^{\prime}\right), \delta_{\mathrm{C}} 115.2\left(\mathrm{C}-2^{\prime}\right), \delta_{\mathrm{C}} 96.3$ (C-6), and $\delta_{\mathrm{C}} 95.8$ (C-8). In the upfield shift, two oxygenated methine carbon signals at $\delta_{\mathrm{C}} 79.8(\mathrm{C}-2)$ and $\delta_{\mathrm{C}} 67.4(\mathrm{C}-3)$, and one methylene carbon signal at $\delta \mathrm{c} 29.2$ (C-4) were observed. Consequently, this compound was identified as $(2 R, 3 R)-5,7,3$ ', 4'-tetrahydroxyflavan-3-ol, (-)-epicatechin, which was further confirmed through a comparison of spectroscopic data, including the specific rotation value $\left([\alpha]_{\mathrm{D}}-57.0^{\circ}\right)$, with data reported in the literature [14].

Compound 4 was obtained as a yellow powder and a molecular ion peak [M] $]^{+}$was observed at $\mathrm{m} / \mathrm{z}$ 318 in the EI/MS spectrum. The IR spectrum showed absorbance bands for hydroxyl $\left(3366 \mathrm{~cm}^{-1}\right)$ and aromatic $\left(1622 \mathrm{~cm}^{-1}\right)$ groups. The ${ }^{1} \mathrm{H}-\mathrm{NMR}$ spectrum showed three olefin methine proton signals at $\delta_{\mathrm{H}}$ $7.11(1 \mathrm{H}, \mathrm{d}, J=2.0 \mathrm{~Hz}), 6.88(1 \mathrm{H}, \mathrm{dd}, J=8.4,2.0 \mathrm{~Hz})$ and $6.77(\mathrm{H}, \mathrm{d}, J=8.4 \mathrm{~Hz})$ of a 1,2,4-trisubstituted benzene ring and two olefin methine proton signals at $\delta_{\mathrm{H}} 6.03(1 \mathrm{H}, \mathrm{d}, J=2.4 \mathrm{~Hz})$ and $6.00(1 \mathrm{H}, \mathrm{d}$, $J=2.4 \mathrm{~Hz}$ ) with evidence of long range coupling $\left({ }^{4} J\right)$ consistent with a 1,2,3,5-tetrasubstituted benzene ring. Two oxygenated methine proton signals at $\delta_{\mathrm{H}} 4.88(1 \mathrm{H}, \mathrm{br}$. s) and $4.17(1 \mathrm{H}, \mathrm{m})$, two methoxy proton signals at $\delta_{\mathrm{H}} 3.85(3 \mathrm{H}, \mathrm{s})$ and $3.75(3 \mathrm{H}, \mathrm{s})$, and methylene proton signals at $\delta_{\mathrm{H}} 2.85(1 \mathrm{H}$, dd, $J=17.2,4.8 \mathrm{~Hz})$ and $2.73(1 \mathrm{H}, \mathrm{dd}, J=17.2,2.8 \mathrm{~Hz})$ were also observed. Thus, compound 4 appeared to be very similar to compound 3 with the exception of two methoxy groups. In the ${ }^{13} \mathrm{C}-\mathrm{NMR}$ spectrum, 17 carbon signals were detected including two methoxy groups. In the downfield shift, there were five oxygenated olefin quaternary carbon signals at $\delta_{\mathrm{C}} 160.5$ (C-7), $\delta_{\mathrm{C}} 158.0(\mathrm{C}-5), \delta_{\mathrm{C}} 157.0(\mathrm{C}-8 \mathrm{a})$, $\delta_{\mathrm{C}} 148.6\left(\mathrm{C}-3^{\prime}\right)$, and $\delta_{\mathrm{C}} 147.0\left(\mathrm{C}-4^{\prime}\right)$, two olefin quaternary carbon signals at $\delta_{\mathrm{C}} 132.2\left(\mathrm{C}-1^{\prime}\right)$ and $\delta_{\mathrm{C}} 100.9(\mathrm{C}-4 \mathrm{a})$, and five olefin methine carbon signals at $\delta_{\mathrm{C}} 120.5\left(\mathrm{C}-6^{\prime}\right), \delta_{\mathrm{C}} 115.6\left(\mathrm{C}-2^{\prime}\right)$, $\delta_{\mathrm{C}} 111.8\left(\mathrm{C}-55^{\prime}\right), \delta_{\mathrm{C}} 96.7(\mathrm{C}-6)$, and $\delta_{\mathrm{C}} 92.8(\mathrm{C}-8)$ due to two benzene rings. In addition, two oxygenated methine carbon signals at $\delta_{\mathrm{C}} 80.0(\mathrm{C}-2)$ and $\delta_{\mathrm{C}} 67.4(\mathrm{C}-3)$ and one methylene carbon signal at $\delta_{\mathrm{C}} 29.3$ (C-4) were observed. Therefore, compound 4 was determined to be a (-)-epicatechin with two methoxy groups. Based on the correlation of the two methoxy signals at $\delta_{\mathrm{H}} 3.85(3 \mathrm{H}, \mathrm{s})$ and $3.75(3 \mathrm{H}, \mathrm{s})$ with the two oxygenated olefin quaternary carbon signals at $\delta_{\mathrm{C}} 158.0$ (C-5) and $\delta_{\mathrm{C}} 148.6$ (C-3') in the gHMBC spectrum, compound 4 was identified as 5,3'-di- $O$-methyl-(-)-epicatechin, which was confirmed by comparison of the spectroscopic data with values reported in the literature [15].

Compound 5 was obtained as colorless needles and a molecular ion peak $[\mathrm{M}]^{+}$was observed at $\mathrm{m} / \mathrm{z} 332$ in the EI/MS spectrum. The IR spectrum showed absorbance bands for hydroxyl $\left(3412 \mathrm{~cm}^{-1}\right)$ and aromatic $\left(1616 \mathrm{~cm}^{-1}\right)$ groups. The ${ }^{1} \mathrm{H}-\mathrm{NMR}$ and ${ }^{13} \mathrm{C}-\mathrm{NMR}$ spectra of compounds 4 and $\mathbf{5}$ were analogous, showing (-)-epicatechin skeleton signals. Due to the $\mathrm{m} / z$ of 332 and observation of three methoxy groups, compound $\mathbf{5}$ was presumed to be (-)-epicatechin-tri- $O$-methylate. To confirm the position of the methoxy groups, a gHMBC experiment was conducted. Judging by the correlation between the three methoxy proton signals at $\delta \mathrm{H} 3.69(6 \mathrm{H}, \mathrm{s})$ and $3.66(3 \mathrm{H}, \mathrm{s})$ with three oxygenated olefin quaternary carbon signals at $\delta_{\mathrm{C}} 160.0$ (C-7), $\delta_{\mathrm{C}} 159.6$ (C-5), and $\delta_{\mathrm{C}} 148.3\left(\mathrm{C}-3^{\prime}\right)$ in the gHMBC spectrum, compound 5 was identified as 5,7,3'-tri- $O$-methyl-(-)-epicatechin, which was confirmed by comparison with spectroscopic data in the literature [15]. 
Compound 6 was obtained as a white amorphous powder and a molecular ion peak $[\mathrm{M}]^{+}$was observed at $\mathrm{m} / \mathrm{z} 330$ in the EI/MS spectrum. The IR spectrum showed absorbance bands of hydroxyl $\left(3408 \mathrm{~cm}^{-1}\right)$ and aromatic $\left(1591 \mathrm{~cm}^{-1}\right)$ groups. The ${ }^{1} \mathrm{H}-\mathrm{NMR}$ spectrum showed that compound 6 had a similar pattern to compound 4 apart from one dioxymethylene signal at $\delta \mathrm{H} 5.94(2 \mathrm{H}, \mathrm{s})$. In the ${ }^{13} \mathrm{C}-\mathrm{NMR}$ spectrum, 18 carbon signals were detected including two methoxy groups $\left(\delta_{\mathrm{C}} 55.4,55.3\right)$ and one dioxymethylene $\left(\delta_{\mathrm{C}} 101.0\right)$ signal. Based on the correlation between the two oxygenated olefin quaternary carbon signals at $\delta_{\mathrm{C}} 147.8\left(\mathrm{C}-3^{\prime}\right)$ and $\delta_{\mathrm{C}} 147.3\left(\mathrm{C}-4^{\prime}\right)$ and the dioxymethlylene proton signal at $\delta_{\mathrm{H}} 5.94(2 \mathrm{H}, \mathrm{s})$, the two oxygenated olefin quaternary carbon signals at $\delta_{\mathrm{C}} 159.6(\mathrm{C}-5)$ and $\delta_{\mathrm{C}} 159.2(\mathrm{C}-7)$, and two methoxy proton signals at $\delta_{\mathrm{H}} 3.76(3 \mathrm{H}, \mathrm{s})$ and $\delta_{\mathrm{H}} 3.74(3 \mathrm{H}, \mathrm{s})$, compound 6 was determined as 5,7-di-O-methyl-3',4'-methylenedioxyflavan-3-ol, which was confirmed by comparison with spectroscopic data in the literature [16].

\subsection{Evaluation of Radical Scavenging Activity and Inhibitory Effect on LDL Oxidation}

Compounds 1 and 3-6 exhibited DPPH radical scavenging with $\mathrm{IC}_{50}$ values of $0.16,0.21,0.17$, 0.15 , and $0.07 \mathrm{mM}$, respectively, which were equivalent with that of ascorbic acid (0.18 $\mathrm{mM})$ (Table 1). The lack of scavenging activity by compound $\mathbf{2}$ was speculated to be due to the glucosyl moiety on the $\mathrm{C}$ ring [17]. Compound $\mathbf{6}$ exhibited the highest antioxidant activity, which we attributed to the dioxymethylene moiety on the $\mathrm{B}$ ring.

Table 1. 1,1-diphenyl-2-picrylhydrazyl (DPPH) radical scavenging activity of flavonoids isolated from the stems of Machilus japonica. ${ }^{a}$ The $\mathrm{IC}_{50}$ value of each compound was defined as the concentration $(\mathrm{mM})$ that resulted in $50 \% \mathrm{DPPH}$ scavenging activity. The results are averages of three independent experiments.

\begin{tabular}{cccccccc}
\hline Compound & $\mathbf{1}$ & $\mathbf{2}$ & $\mathbf{3}$ & $\mathbf{4}$ & $\mathbf{5}$ & $\mathbf{6}$ & Ascorbic Acid \\
\hline $\mathrm{IC}_{50}(\mathrm{mM})^{a}$ & 0.16 & - & 0.21 & 0.17 & 0.15 & 0.07 & 0.18 \\
\hline
\end{tabular}

Highly reactive molecules called free radicals can cause tissue damage by reacting with polyunsaturated fatty acids in cellular membranes, nucleotides in DNA, and critical sulfhydryl bonds in proteins. In addition to cellular damage, cataract formation, photodermatoses, aging, and inflammatory diseases such as arthritis are associated with free radicals [18]. Therefore, the search for compounds from natural sources that can protect against free radicals by endogenous and exogenous antioxidants is of special significance for human health.

Antioxidants act by donating hydrogen atoms to lipid radicals. Radicals obtained from antioxidants with molecular structures such as phenols are stable species that can halt the oxidation chain reaction [19]. To determine whether these compounds might be effective in the development of hypercholesterolemic or antiatherogenic agents, their potential for inhibiting LDL oxidation was evaluated.

Compounds 1, 3, and 5 demonstrated LDL antioxidant activity with $\mathrm{IC}_{50}$ values of 2.8, 7.1, and 4.6 $\mu \mathrm{M}$, respectively (Table 2). Compound 1 was similar to the positive control, BHT, which had an $\mathrm{IC}_{50}$ value of $1.9 \mu \mathrm{M}$, while compounds $\mathbf{3}$ and $\mathbf{5}$ also showed significant activity. Compound $\mathbf{4}$ exhibited a low level of LDL antioxidant activity with an $\mathrm{IC}_{50}$ value of $79.1 \mu \mathrm{M}$. Compounds 2 and 6 were not effective as LDL antioxidants, which was attributed to the glucosyl moiety at C-3 for 
compound 2 and steric hindrance of the hydroxyl groups at C-3' and C-4' by dioxymethylene moieties in compound $\mathbf{6}$.

Table 2. Inhibitory effects of flavonoids isolated from the stems of Machilus japonica on low-density lipoprotein (LDL) oxidation. ${ }^{a}$ The $\mathrm{IC}_{50}$ value of each compound was defined as the concentration $(\mu \mathrm{M})$ that resulted in $50 \%$ inhibition of LDL oxidation. The results are averages of three independent experiments, and the data are expressed as the mean $\pm \mathrm{SD}$.

\begin{tabular}{|c|c|c|c|c|c|}
\hline \multirow{2}{*}{ Compound } & \multicolumn{4}{|c|}{ Inhibition Effect (\%) } & \multirow{2}{*}{$\mathrm{IC}_{50}(\mu \mathrm{M})^{a}$} \\
\hline & $5 \mu \mathrm{M}$ & $10 \mu \mathrm{M}$ & $40 \mu \mathrm{M}$ & $80 \mu \mathrm{M}$ & \\
\hline 1 & $90.1 \pm 0.0$ & $95.8 \pm 0.6$ & $100.4 \pm 0.0$ & $104.2 \pm 1.5$ & $2.8 \pm 0.5$ \\
\hline 2 & - & - & - & $3.0 \pm 1.8$ & $>50$ \\
\hline 3 & $23.1 \pm 2.6$ & $93.6 \pm 1.6$ & $99.0 \pm 0.2$ & $104.0 \pm 0.0$ & $7.1 \pm 1.1$ \\
\hline 4 & - & - & - & $51.8 \pm 0.2$ & $>50$ \\
\hline 5 & $58.9 \pm 0.7$ & $65.3 \pm 1.4$ & $72.9 \pm 0.5$ & $84.2 \pm 0.7$ & $4.6 \pm 0.8$ \\
\hline 6 & - & - & - & $13.7 \pm 0.2$ & $>50$ \\
\hline BHT & - & - & - & - & $1.9 \pm 0.4$ \\
\hline
\end{tabular}

LDL oxidation is regarded as a key step in the formation of atherosclerotic lesions [20,21]. Experimental evidence demonstrating an association between oxLDL cholesterol and both the presence of atherosclerotic lesions and progression of carotid artery atherosclerosis support this hypothesis [22,23]. Vitamin E, one of the most popular natural antioxidants, inhibits atherogenesis by inhibiting LDL oxidation ( $\mathrm{IC}_{50}: 2.4 \mu \mathrm{M}$ ) [24]. Several other effective natural dietary antioxidants comprising phenolic compounds and carotenoids have been identified as well, in addition to vitamins and enzymes [25]. The inhibitory activity of compounds $\mathbf{1}, \mathbf{3}$, and $\mathbf{5}$ was very similar to that of the well-known antioxidant BHT ( $\mathrm{IC}_{50}: 1.9 \mu \mathrm{M}$ ), and showed significant antioxidant capacity relative to several other naturally-occurring antioxidants such as nectandrin B ( $\left.\mathrm{IC}_{50}: 4.1 \mu \mathrm{M}\right)$ from tabu (Machilus thunbergii) [26] and (+)-lariciresinol (IC50: $11.9 \mu \mathrm{M}$ ) from Rousa dogwood (Cornus kousa) [27]. Therefore, the flavonoids isolated from Machilus japonica may be a good natural source of antiatherogenic agents.

\section{Experimental Section}

\subsection{Plant Materials}

Dried stems of Machilus japonica were supplied by GFC Co., Ltd., Suwon, Korea in January 2010, and were identified by Dae-Keun Kim, College of Pharmacy, Woosuk University, Jeonju, Korea. A voucher specimen (KHU2010-0103) has been reserved at the Laboratory of Natural Product Chemistry, Kyung Hee University, Yongin, Korea.

\subsection{General Experimental Procedures}

Melting points were determined using a Fisher-John's Melting Point apparatus (Fisher Scientific, Miami, FL, USA) with a microscope and the values obtained were uncorrected. Optical rotations were measured using a JASCO P-1010 digital polarimeter (Tokyo, Japan). NMR spectra were recorded on a 
$400 \mathrm{MHz}$ FT-NMR spectrometer (Varian Inova AS 400, Palo Alto, CA, USA). IR spectra were obtained from a Perkin Elmer Spectrum One FT-IR spectrometer (Buckinghamshire, England). FAB-MS data were recorded on a JEOL JMS-700 (Tokyo, Japan), EI-MS on a JEOL JMSAX 505-WA (Tokyo, Japan), and ESI-MS on a Finnigan LCQ Advantage spectrometer (Thermo Scientific, Waltham, MD, USA). The UV lamp used was a Spectroline Model ENF-240 C/F (Spectronics Corporation, Westbury, NY, USA). Kiesel gel 60 silica gel resin was used for column chromatography (c.c.) (Merck, Darmstadt, Germany) and the ODS was a LiChroprep RP-18 (Merck). TLC analysis was carried out using Kiesel gel $60 \mathrm{~F}_{254}$ and RP-18 F254S (Merck). Deuterated solvents were purchased from Merck Co. Ltd. and Sigma Aldrich Co. Ltd. (St. Louis, MO, USA).

\subsection{Isolation of Flavonoids from the EtOAc Fraction Obtained from M. japonica Stems}

Dried and pulverized stems $(9 \mathrm{~kg})$ of $M$. japonica were extracted with $80 \%$ aqueous $\mathrm{MeOH}(25 \mathrm{~L} \times 3)$ at room temperature for $24 \mathrm{~h}$. Concentrated $\mathrm{MeOH}$ extracts were suspended in $\mathrm{H}_{2} \mathrm{O}(3 \mathrm{~L})$ and then successively extracted with ethyl acetate (EtOAc, $3 \mathrm{~L} \times 4)$ and $n$-butanol $(n-\mathrm{BuOH}, 2.4 \mathrm{~L} \times 3)$. The solutions were again concentrated to produce an EtOAc fraction (MJE, $56 \mathrm{~g}$ ), $n$-BuOH fraction (MJB, $75 \mathrm{~g}$ ), and $\mathrm{H}_{2} \mathrm{O}$ fraction (MJW, $229 \mathrm{~g}$ ). The EtOAc fraction extract was applied to silica gel $\left(\mathrm{SiO}_{2}\right)$ c.c. $(\varphi 10 \mathrm{~cm} \times 16 \mathrm{~cm})$, eluted with chloroform $\left(\mathrm{CHCl}_{3}\right)-\mathrm{MeOH}(15: 1 \rightarrow 12: 1 \rightarrow 10: 1 \rightarrow 8: 1 \rightarrow 5: 1 \rightarrow 1: 1$, 3.2 L each), and monitored by TLC to produce 18 fractions (MJE-1 to MJE-18). Fraction MJE-2 [7.4 g, elution volume/total volume (Ve/Vt) $0.03-0.08]$ was applied to $\mathrm{SiO}_{2}$ c.c. $(\varphi 7 \mathrm{~cm} \times 12 \mathrm{~cm})$ and eluted with $n$-hexane-EtOAc $(8: 1 \rightarrow 4: 1 \rightarrow 1: 1,4 \mathrm{~L}$ each) to produce 16 fractions (MJE-2-1 to MJE-2-16). Among these, fraction MJE-2-10 (490 mg, Ve/Vt 0.42-0.51) was separated by ODS c.c. $(\varphi 3.5 \mathrm{~cm} \times 4.5 \mathrm{~cm})$ using acetone- $\mathrm{H}_{2} \mathrm{O}(1: 3,3 \mathrm{~L} \rightarrow 1: 1,4 \mathrm{~L})$ as the elution solvent to obtain compound 6 [MJE-2-10-5, $17 \mathrm{mg}$, $\mathrm{Ve} / \mathrm{Vt}$ 0.45-0.52, TLC (RP-18 F254s) Rf 0.49, acetone- $\left.\mathrm{H}_{2} \mathrm{O}=3: 1\right]$. Fraction MJE-2-13 (512 mg, Ve/Vt $0.75-0.81)$ was subjected to $\mathrm{SiO}_{2}$ c.c. $(\varphi 3.5 \mathrm{~cm} \times 12 \mathrm{~cm})$ with $n$-hexane-CHCl $3-\mathrm{MeOH}(20: 10: 1,1 \mathrm{~L})$ as the elution solvent to produce seven fractions (MJE-2-13-1 to MJE-2-13-7). Fraction MJE-2-13-3 (143 mg, Ve/Vt 0.38-0.44) was applied to ODS c.c. $(\varphi 3 \mathrm{~cm} \times 5.5 \mathrm{~cm})$ using $\mathrm{MeOH}-\mathrm{H}_{2} \mathrm{O}(1: 4,2.8 \mathrm{~L})$ as the elution solvent to yield compound 5 [MJE-2-13-3-10, $28 \mathrm{mg}$, Ve/Vt 0.75-0.77, TLC (RP-18 $\left.\mathrm{F}_{254 \mathrm{~S}}\right) \mathrm{R}_{\mathrm{f}} 0.75$, acetone- $\left.\mathrm{H}_{2} \mathrm{O}=2: 1\right]$. Fraction MJE-3 (3.8 g, Ve/Vt 0.08-0.13) was applied to $\mathrm{SiO}_{2}$ c.c. $(\varphi 7 \mathrm{~cm} \times 12 \mathrm{~cm})$ and eluted with $n$-hexane-EtOAc $(10: 1,20 \mathrm{~L})$ to produce 20 fractions (MJE-3-1 to MJE-3-20). Fraction MJE-3-17 (120 mg, Ve/Vt 0.66-0.68) was separated by ODS c.c. $(\varphi 3.0 \mathrm{~cm} \times 5.0 \mathrm{~cm})$ using acetone- $\mathrm{H}_{2} \mathrm{O}(1: 5,2.2 \mathrm{~L})$ as the elution solvent to obtain compound 4 [MJE-3-17-4, $17 \mathrm{mg}, \mathrm{Ve} / \mathrm{Vt}$ 0.45-0.52, TLC (RP-18 F 254S) $\mathrm{R}_{\mathrm{f}} 0.46$, acetone- $\left.\mathrm{H}_{2} \mathrm{O}=1: 1\right]$. Fraction MJE-11 (2.4 g, Ve/Vt 0.50-0.55) was applied to ODS c.c. $(\varphi 3.5 \mathrm{~cm} \times 7 \mathrm{~cm})$ and eluted with $\mathrm{MeOH}-\mathrm{H}_{2} \mathrm{O}(1: 5 \rightarrow 1: 3 \rightarrow 1: 1 \rightarrow 3: 1 \rightarrow$ 10:1, 1.6 L each) to produce 18 fractions (MJE-11-1 to MJE-11-18). Fraction MJE-11-6 (123 mg, $\mathrm{Ve} / \mathrm{Vt} 0.25-0.37)$ was subjected to ODS c.c. $(\varphi 3 \mathrm{~cm} \times 5 \mathrm{~cm})$ and eluted with $\mathrm{MeOH}-\mathrm{H}_{2} \mathrm{O}(1: 2,1.6 \mathrm{~L})$ to produce eight fractions (MJE-11-6-1 to MJE-11-6-8). Fraction MJE-11-6-1 (49 mg, Ve/Vt 0.00-0.07) was subjected to $\mathrm{SiO}_{2}$ c.c. $(\varphi 2 \mathrm{~cm} \times 11 \mathrm{~cm})$ and eluted with $\mathrm{CHCl}_{3}-\mathrm{MeOH}-\mathrm{H}_{2} \mathrm{O}(10: 3: 1,1.1 \mathrm{~L})$ to yield compound 3 [MJE-11-6-1-4, 9.5 mg, Ve/Vt 0.31-0.76, TLC (RP-18 F $254 \mathrm{~S}$ ) $\mathrm{R}_{\mathrm{f}}$ 0.69, acetone- $\mathrm{H}_{2} \mathrm{O}=1: 1$ ] Fraction MJE-11-6-3 (33 mg, Ve/Vt 0.18-0.24) was subjected to ODS c.c. $(\varphi 2 \mathrm{~cm} \times 7 \mathrm{~cm})$ and eluted with acetone- $\mathrm{H}_{2} \mathrm{O}(1: 3,350 \mathrm{~mL})$ to yield compound 1 [MJE-11-6-3-3, $18 \mathrm{mg}, \mathrm{Ve} / \mathrm{Vt} 0.46-0.99$, TLC (RP-18 $\left.\mathrm{F}_{254 \mathrm{~S}}\right) \mathrm{R}_{\mathrm{f}}$ 0.50, acetone- $\left.\mathrm{H}_{2} \mathrm{O}=1: 1\right]$. Finally, fraction MJE-11-11 (180 mg, Ve/Vt 
0.50-0.53) was subjected to $\mathrm{SiO}_{2}$ c.c. $(\varphi 3 \mathrm{~cm} \times 13 \mathrm{~cm})$ and eluted with $\mathrm{CHCl}_{3}-\mathrm{MeOH}_{2} \mathrm{H}_{2} \mathrm{O}(13: 3: 1$, $1.1 \mathrm{~L})$ to yield compound 2 [MJE-11-11-6, $9.6 \mathrm{mg}$, Ve/Vt 0.31-0.76, TLC (F254s) Rf 0.51, $\left.\mathrm{CHCl}_{3}-\mathrm{MeOH}-\mathrm{H}_{2} \mathrm{O}=7: 3: 1\right]$.

Compound $1\left((+)\right.$-taxifolin). Yellow amorphous powder (MeOH); m.p. $231{ }^{\circ} \mathrm{C} ;[\alpha]_{\mathrm{D}}+42.0^{\circ}(c=0.50$, $\mathrm{MeOH}$ ); IR (CaF2 plate, v) 3420, 2931, 2885, 1620, 1520, 1470, 1360, 1265, $1165 \mathrm{~cm}^{-1}$; positive FAB-MS $m / z 305[\mathrm{M}+\mathrm{H}]^{+}$; ${ }^{1} \mathrm{H}-\mathrm{NMR}\left(400 \mathrm{MHz}, \mathrm{CD}_{3} \mathrm{OD}, \delta\right) 6.95\left(1 \mathrm{H}, \mathrm{d}, J=2.0 \mathrm{~Hz}, \mathrm{H}-2^{\prime}\right), 6.83(1 \mathrm{H}, \mathrm{dd}, J=8.0$, $2.0 \mathrm{~Hz}, \mathrm{H}-6$ '), $6.79\left(1 \mathrm{H}, \mathrm{d}, J=8.0 \mathrm{~Hz}, \mathrm{H}-5^{\prime}\right), 5.90(1 \mathrm{H}, \mathrm{d}, J=2.0 \mathrm{~Hz}, \mathrm{H}-8), 5.86(1 \mathrm{H}, \mathrm{d}, J=2.0 \mathrm{~Hz}, \mathrm{H}-6)$, $4.89(1 \mathrm{H}, \mathrm{d}, J=11.6 \mathrm{~Hz}, \mathrm{H}-2), 4.49$ (1H, d, $J=11.6 \mathrm{~Hz}, \mathrm{H}-3) ;{ }^{13} \mathrm{C}-\mathrm{NMR}\left(100 \mathrm{MHz}, \mathrm{CD}_{3} \mathrm{OD}, \delta\right) 198.1$ (C-4), 168.5 (C-7), 165.1 (C-5), 164.2 (C-8a), 146.9 (C-4'), 146.1 (C-3'), 129.6 (C-1'), 120.7 (C-6'), 115.9 (C-2'), 115.7 (C-5'), 100.4 (C-4a), 97.2 (C-6), 96.1 (C-8), 85.0 (C-2), 73.5 (C-3).

Compound 2 (afzelin). Yellow amorphous powder $(\mathrm{MeOH})$; m.p. $173{ }^{\circ} \mathrm{C}$; $[\alpha]_{\mathrm{D}}-184.0^{\circ}(c=0.10$, $\mathrm{MeOH})$; IR ( $\mathrm{CaF}_{2}$ plate, v) 3280, 2977, 2937, 1655, 1615, 1500, 1450, $1365 \mathrm{~cm}^{-1}$; ESI-MS m/z 431 $[\mathrm{M}-\mathrm{H}]^{-}$; ${ }^{1} \mathrm{H}-\mathrm{NMR}\left(400 \mathrm{MHz}, \mathrm{CD}_{3} \mathrm{OD}, \delta\right) 7.75$ (2H, br. d, $J=8.8 \mathrm{~Hz}, \mathrm{H}-2$ ', 6'), 6.92 (2H, br. d, $\left.J=8.8 \mathrm{~Hz}, \mathrm{H}-3^{\prime}, 5^{\prime}\right), 6.37(1 \mathrm{H}, \mathrm{d}, J=2.0 \mathrm{~Hz}, \mathrm{H}-8), 6.19(1 \mathrm{H}, \mathrm{d}, J=2.0 \mathrm{~Hz}, \mathrm{H}-6), 5.36(1 \mathrm{H}, \mathrm{d}, J=1.6 \mathrm{~Hz}$, H-1"), 4.21 (1H, dd, $J=2.8,1.6$ Hz, H-2"), 3.93-3.68 (3H, m, H-3", 4", 5"), 0.91 (3H, d, J=5.6 Hz, H-6"); ${ }^{13} \mathrm{C}-\mathrm{NMR}\left(100 \mathrm{MHz}, \mathrm{CD}_{3} \mathrm{OD}, \delta\right) 178.0$ (C-4), 164.3 (C-5), 161.1 (C-4a), 160.0 (C-4'), 157.2 (C-2), 157.0 (C-7), 134.6 (C-3), 130.4 (C-2', 6'), 121.1 (C-1'), 115.0 (C-3', 5'), 108.4 (C-8a), 102.0 (C-1"), 98.4 (C-6), 93.3 (C-8), 71.7 (C-4"), 70.7 (C-3"), 70.6 (C-5"), 70.5 (C-2"), 16.3 (C-6").

Compound 3 ((-)-epicatechin). Yellow amorphous powder $(\mathrm{MeOH})$; m.p. $243{ }^{\circ} \mathrm{C}$; $[\alpha]_{\mathrm{D}}-57.0^{\circ}$ $(c=0.50, \mathrm{MeOH})$; IR (KBr, v) 3450, 2935, 1525, 1469, 1438, 1263, $1184 \mathrm{~cm}^{-1}$; EI-MS m/z $290[\mathrm{M}]^{+}$; ${ }^{1} \mathrm{H}-\mathrm{NMR}\left(400 \mathrm{MHz}, \mathrm{CD}_{3} \mathrm{OD}, \delta\right) 6.96\left(1 \mathrm{H}, \mathrm{d}, J=1.6 \mathrm{~Hz}, \mathrm{H}-2^{\prime}\right), 6.78\left(1 \mathrm{H}, \mathrm{dd}, J=8.0,1.6 \mathrm{~Hz}, \mathrm{H}-6{ }^{\prime}\right)$, $6.75\left(1 \mathrm{H}, \mathrm{d}, J=8.0 \mathrm{~Hz}, \mathrm{H}-5^{\prime}\right), 5.93(1 \mathrm{H}, \mathrm{d}, J=1.6 \mathrm{~Hz}, \mathrm{H}-8), 5.91(1 \mathrm{H}, \mathrm{d}, J=1.6 \mathrm{~Hz}, \mathrm{H}-6), 4.80(1 \mathrm{H}$, br. s, H-2), 4.16 (1H, m, H-3), 2.85 (1H, dd, $J=16.8,4.8 \mathrm{~Hz}, \mathrm{H}-4 \beta), 2.73$ (1H, dd, $J=16.8,2.8 \mathrm{~Hz}, \mathrm{H}-4 \alpha$ ); ${ }^{13} \mathrm{C}-\mathrm{NMR}$ (100 MHz, CD $\left.{ }_{3} \mathrm{OD}, \delta\right) 157.9$ (C-5), 157.5 (C-7), 157.3 (C-8a), 145.8 (C-4'), 145.7(C-3'), 132.2 (C-1'), 119.3 (C-6'), 115.8 (C-5'), 115.2 (C-2'), 100.0 (C-4a), 96.3 (C-6), 95.8 (C-8), 79.8 (C-2), 67.4 (C-3), 29.2 (C-4).

Compound 4 (5,3'-di-O-methyl-(-)-epicatechin). Yellow powder $\left(\mathrm{CHCl}_{3}\right) ;$ m.p. $267{ }^{\circ} \mathrm{C} ;[\alpha]_{\mathrm{D}}-75.0^{\circ}$ $(c=0.50, \mathrm{MeOH})$; IR $\left(\mathrm{CaF}_{2}\right.$ plate, $\left.v\right) 3366,2956,2862,2340,1622,1503,1373,1270,1145 \mathrm{~cm}^{-1}$; EI-MS $m / z 318[\mathrm{M}]^{+}$; ${ }^{1} \mathrm{H}-\mathrm{NMR}\left(400 \mathrm{MHz}, \mathrm{CDCl}_{3}, \delta\right) 7.11(1 \mathrm{H}, \mathrm{d}, J=2.0 \mathrm{~Hz}, \mathrm{H}-2$ '), $6.88(1 \mathrm{H}, \mathrm{dd}, J=8.4$, $2.0 \mathrm{~Hz}, \mathrm{H}-6$ '), $6.77\left(1 \mathrm{H}, \mathrm{d}, J=8.4 \mathrm{~Hz}, \mathrm{H}-5{ }^{\prime}\right), 6.03(1 \mathrm{H}, \mathrm{d}, J=2.4 \mathrm{~Hz}, \mathrm{H}-8), 6.00(1 \mathrm{H}, \mathrm{d}, J=2.4 \mathrm{~Hz}, \mathrm{H}-6)$, 4.88 (1H, br. s, H-2), 4.17 (1H, m, H-3), 3.85 (3H, s, O-Me), 3.75 (3H, s, O-Me), 2.85 (1H, dd, J= 17.2, $4.8 \mathrm{~Hz}, \mathrm{H}-4 \beta), 2.73(1 \mathrm{H}, \mathrm{dd}, J=17.2,2.8 \mathrm{~Hz}, \mathrm{H}-4 \alpha) ;{ }^{13} \mathrm{C}-\mathrm{NMR}\left(100 \mathrm{MHz}, \mathrm{CD}_{3} \mathrm{OD}, \delta\right) 160.5(\mathrm{C}-7)$, 158.0 (C-5), 157.0 (C-8a), 148.6 (C-3'), 147.0 (C-4'), 132.2 (C-1'), 120.5 (C-6'), 115.6 (C-2'), 111.8 (C-5'), 100.9 (C-4a), 96.7 (C-6), 92.8 (C-8), 80.0 (C-2), 67.4 (C-3), 56.3 (O-Me), 55.8 (O-Me), 29.3 (C-4).

Compound 5 (5,7,3'-tri-O-methyl-(-)-epicatechin). Colorless needles $\left(\mathrm{C}_{5} \mathrm{H}_{5} \mathrm{~N}\right)$; m.p. $139{ }^{\circ} \mathrm{C}$; $[\alpha]_{\mathrm{D}}-62^{\circ}(c=1.22$, acetone $)$; IR $\left(\mathrm{CaF}_{2}\right.$ plate, $\left.v\right) 3412,2933,2838,1616,1590,1519,1493,1271$, $1145 \mathrm{~cm}^{-1}$; EI-MS m/z $332[\mathrm{M}]^{+},{ }^{1} \mathrm{H}-\mathrm{NMR}\left(400 \mathrm{MHz}, \mathrm{C}_{5} \mathrm{D}_{5} \mathrm{~N}, \delta\right) 7.37$ (1H, dd, $\left.J=8.0,1.6 \mathrm{~Hz}, \mathrm{H}-6^{\prime}\right)$, $7.28\left(1 \mathrm{H}, \mathrm{d}, J=8.0 \mathrm{~Hz}, \mathrm{H}-5^{\prime}\right), 7.19\left(1 \mathrm{H}, \mathrm{d}, J=1.6 \mathrm{~Hz}, \mathrm{H}-2^{\prime}\right), 6.52$ (1H, br. s, H-6), 6.32 (1H, br. s, H-8), $5.25(1 \mathrm{H}$, br. s, H-2), $4.62(1 \mathrm{H}, \mathrm{m}, \mathrm{H}-3), 3.69(6 \mathrm{H}, \mathrm{s}, \mathrm{O}-\mathrm{Me}), 3.66(3 \mathrm{H}, \mathrm{s}, \mathrm{O}-\mathrm{Me}), 3.30(1 \mathrm{H}, \mathrm{dd}, J=16.8$, $4.4 \mathrm{~Hz}, \mathrm{H}-4 \beta), 3.15$ (1H, dd, $J=16.8,2.8 \mathrm{~Hz}, \mathrm{H}-4 \alpha)$; ${ }^{13} \mathrm{C}-\mathrm{NMR}\left(100 \mathrm{MHz}, \mathrm{C}_{5} \mathrm{D}_{5} \mathrm{~N}, \delta\right) 160.0(\mathrm{C}-7)$, 159.6 (C-5), 156.8 (C-8a), 148.3 (C-3'), 147.7 (C-4'), 131.4 (C-1'), 120.6 (C-6'), 116.0 (C-2'), 112.1 (C-5'), 102.0 (C-4a), 94.2 (C-6), 91.9 (C-8), 79.9 (C-2), 66.2 (C-3), 55.7 (O-Me), 55.2 (O-Me × 2), 29.5 (C-4). 
Compound 6 (5,7-di-O-methyl-3',4'-methylenedioxyflavan-3-ol). White amorphous powder $\left(\mathrm{CHCl}_{3}\right)$; m.p. $158{ }^{\circ} \mathrm{C}$; $[\alpha]_{\mathrm{D}}-34^{\circ}\left(c=0.20, \mathrm{CHCl}_{3}\right)$; IR $\left(\mathrm{CaF}_{2}\right.$ plate, v) 3408, 2920, 2836, 2331, 1591, 1537, 1464, 1252, $1145 \mathrm{~cm}^{-1}$; EI-MS m/z $330[\mathrm{M}]^{+}$; ${ }^{1} \mathrm{H}-\mathrm{NMR}\left(400 \mathrm{MHz}, \mathrm{CDCl}_{3}, \delta\right) 7.02$ (1H, br. s, H-2'), 6.93 (1H, br. d, $\left.J=7.2 \mathrm{~Hz}, \mathrm{H}-6^{\prime}\right), 6.82\left(1 \mathrm{H}, \mathrm{d}, J=7.2 \mathrm{~Hz}, \mathrm{H}-5^{\prime}\right), 6.15$ (1H, br. s, H-8), 6.09 (1H, br. s, H-6), 5.94 (2H, s, -O-CH2-O-), 4.90 (1H, br. s, H-2), 4.22 (1H, m, H-3), 3.76 (3H, s, O-Me), 3.74 (3H, s, O-Me), 2.83-2.93 (2H, m, H-4 $\alpha, \beta) ;{ }^{13} \mathrm{C}-\mathrm{NMR}\left(100 \mathrm{MHz}, \mathrm{CD}_{3} \mathrm{OD}, \delta\right) 159.6$ (C-5), 159.2 (C-7), 155.1 (C-8a), 147.8 (C-3'), 147.3 (C-4'), 132.1 (C-1'), 119.6 (C-6'), 108.2 (C-5'), 107.1 (C-2'), 101.0 (-O-CH2-O-), 93.2 (C-8), 92.1 (C-6), 78.4 (C-2), 66.3 (C-3), 55.4 (O-Me), 55.3 (O-Me), 28.1 (C-4).

\subsection{DPPH Radical Scavenging Activity}

The DPPH radical scavenging activity assay was based on the capacity of a substance to scavenge stable DPPH radicals. Briefly, reaction mixtures containing test samples $(100 \mu \mathrm{L})$ and an ethanolic DPPH solution $(100 \mu \mathrm{L}$ of $0.06 \mathrm{mM})$ were placed in 96 -well microplates and incubated at $37{ }^{\circ} \mathrm{C}$ for $30 \mathrm{~min}$. Absorbance values were measured at $517 \mathrm{~nm}$.

\subsection{LDL Isolation and Oxidation Assay}

Plasma was obtained from fasted healthy normalipidemic volunteers. LDL isolation and TBARS assays were performed as previously described with slight modification [28]. Briefly, an LDL solution (250 $\mu \mathrm{L}, 50-100 \mu \mathrm{g}$ protein) in $10 \mathrm{mM}$ PBS (pH 7.4) was supplemented with $10 \mu \mathrm{M} \mathrm{CuSO}$. Oxidation was performed in screw-capped 5-mL glass vials at $37{ }^{\circ} \mathrm{C}$ in the presence of either compound $\mathbf{1}, \mathbf{3}$, or $\mathbf{5}$. After incubation for $4 \mathrm{~h}$ the reaction was terminated by the addition of $1 \mathrm{~mL} 20 \% \mathrm{TCA}$. Following precipitation, $1 \mathrm{~mL} 0.67 \%$ TBA in $0.05 \mathrm{~N} \mathrm{NaOH}$ was added and the mixture was vortexed, after which the final mixture was heated for $5 \mathrm{~min}$ at $95{ }^{\circ} \mathrm{C}$, cooled on ice, and centrifuged for 2 min at $1000 \times g$. The optical density of MDA generated in the assay was measured at $532 \mathrm{~nm}$. Calibration was performed using an MDA standard prepared from tetramethoxypropane.

\section{Conclusions}

In this study, six flavonoids were isolated from the stem of $M$. japonica for the first time. The isolated compounds were identified as (+)-taxifolin, afzelin, (-)-epicatechin, 5,3'-di- $O$-methyl-(-)-epicatechin, 5,7,3'-tri-O-methyl-(-)-epicatechin, and 5,7-di- $O$-methyl-3',4'-methylenedioxyflavan-3-ol based on spectroscopic analyses. The flavonoids showed DPPH radical scavenging activity and inhibitory effects on LDL oxidation. Therefore, extracts of $M$. japonica stems and the flavonoids contained therein may be useful for preventing or treating hypercholesterolemia and atherosclerosis.

\section{Supplementary Materials}

Supplemenatry Figures can be found at http://www.mdpi.com/1422-0067/15/9/16418/s1.

\section{Acknowledgments}

We gratefully acknowledge The Innovation of Technology Development Project (No. S2091482), Korea Evaluation Institute of Industrial Technology, Republic of Korea for providing research funding. 


\section{Author Contributions}

S.-J.J., H.C.K., H.-S.K., and S.-Y.B. isolated flavonoids; H.-J.P., J.-H.P., J.-G.C., and D.-Y.L. determined the chemical structures of the flavonids; J.-H.K. and T.-S.J. evaluated for DPPH radical scavenging effect and inhibitory activity on LDL oxidation; and N.-I.B. drafted this study and coordinated the role of each researcher; The manuscript was written by S.-J.J. and checked by N.-I.B.

\section{Conflicts of Interest}

The authors declare no conflict of interest.

\section{References}

1. Heywood, V.H. Flowering Plants of the World, 1st ed.; Academy Publishing Co.: Seoul, Korea, 1991; p. 11.

2. Takaoka, D.; Watanabe, K.; Hiroi, M. Studies on lignoids in Lauraceae. II. Studies on lignans in the leaves of Machilus japonica Siebold \& Zucc. Bull. Chem. Soc. Jpn. 1976, 49, 3564-3566.

3. Khien, P.V.; Huy, D.Q.; Huong, D.T.V. Chemical composition of essential oil of Machilus japonica Sieb. \& Zucc. (Lauraceae) from Vietnam. VNU J. Sci. Nat. Sci. Technol. 2009, 25, 81-83.

4. Gonzalez-Coloma, A.; Escoubas, P.; Mizutani, J.; Lajide, L. Insect growth inhibitors from Machilus japonica. Phytochemistry 1994, 3, 607-610.

5. Moon, J.Y.; Yim, E.Y.; Song, G.; Lee, N.H.; Hyun, C.G. Screening of elastase and tyrosinase inhibitory activity from Jeju Island plants. Eur. Asia. J. BioSci. 2010, 4, 41-53.

6. Lee, Y.L.; Lee, M.H.; Chang, P.Y.; Huang, I.J.; Cheng, K.T.; Leu, S.J. Taiwanese native plants inhibit matrix metalloproteinase-9 activity after ultraviolet B irradiation. Molecules 2009, 14, 1062-1071.

7. Re, R.; Pellegrini, N.; Proteggente, A.; Pannala, A.; Yang, M.; Rice-Evans, C. Antioxidant activity applying an improved ABTS ridical cation decolorization assay. Free Radic. Biol. Med. 1999, 26, 1231-1237.

8. Steinberg, D. Oxidative modification of LDL and atherogenesis. Circulation 1997, 95, 1062-1071.

9. Glass, C.K. Atherosclerosis: A the road ahead. Cell 2001, 23, 503-516.

10. Kuspradinl, H.; Mitsunaga, T.; Ohashi, H. Antimicrobial activity against Streptococcus sobrinus and glucosyltransferase inhibitory activity of taxifolin and some flavanonol rhamnosides from kempas (Koompassia malaccensis) extracts. J. Wood Sci. 2009, 55, 308-313.

11. Imai, T.; Inoue, S.; Ohdaira, N.; Matsushita, Y.; Suzuki, R.; Sakurai, M.; Henriques de Jesus, J.M.; Ozaki, S.K.; Finger, Z.; Fukushima, K. Heartwood extractives from the Amazonian trees Dipteryx odorata, Hymenaea courbaril, and Astonium lecointei and their antioxidant activities. J. Wood Sci. 2008, 54, 470-475.

12. Kim, Y.K.; Kim, Y.S.; Choi, S.U.; Ryu, S.Y. Isolation of flavonol rhamnosides from Loranthus tanakae and cytotoxic effect of them on human tumor cell lines. Arch. Pham. Res. 2004, 27, 44-47.

13. Kim, D.K. Antioxidative constituents from the whole plant of Actinostemma lobatum Maxim. J. Korean Soc. Appl. Biol. Chem. 2010, 53, 746-751. 
14. Masika, P.J.; Sultana, N.; Afolayan, A.J. Antibacterial activity of two flavonoids isolated from Schotia latifolia. Pharm. Biol. 2004, 42, 105-108.

15. Morimoto, S.; Nonak, G.I.; Nishioka, I.; Ezaki, N.; Takizawa, N. Tannins and related compounds. XXIX.1) Seven new methyl derivatives of flavan-3-ols and a 1,3-diarylpropan-2-ol from Cinnamomum cassia, C. obtusifolium and Lindera umbellata var. membranacea. Chem. Pharm. Bull. 1985, 33, 2281-2286.

16. Ku, Y.L.; Chen, C.H.; Lee, S.S. Chemical constituents from Phoebe minutiflora II. Nat. Prod. Res. 2006, 13, 1199-1206.

17. Yokozawa, T.; Chen, C.P.; Dong, E.; Tanaka, T.; Nonaka, G.I.; Nishioka, I. Study on the inhibitory effect of tannins and flavonoids against the 1,1-diphenyl-2-picrylhydrazyl radical. Biochem. Pharmacol. 1998, 56, 213-222.

18. Lawrence, J.; Machlin, L.J.; Bendich, A. Free radical tissue damage: Protective role of antioxidant nutrients. FASEB J.1987, 6, 441-445.

19. Bondet, V.; Brand-Williams, W.; Berset, C. Kinetics and mechanisms of antioxidant activity using the DPPH free radical method. Lebensm. Wiss. Technol. 1997, 30, 609-615.

20. Steinberg, D.; Parthasarathy, S.; Carew, T.E.; Khoo, J.C.; Witztum, J.L. Beyond cholesterol. Modification of low density lipoprotein that increases its atherogenicity. N. Engl. J. Med. 1989, 320, 915-924.

21. Diaz, M.N.; Frei, B.; Vita, J.A.; Keaney, J.F. Antioxidants and atherosclerotic heart disease. N. Engl. J. Med. 1997, 337, 408-416.

22. Regnstrom, J.; Nilsson, J.; Tornvall, P.; Hamsten, A.; Landou, C. Susceptibility to low-density lipoprotein oxidation and coronary atherosclerosis in man. Lancet 1992, 339, 1183-1186.

23. Salonen, J.T.; Yla-Herttuala, S.; Yamamoto, R.; Butler, S.; Korpela, H.; Salonen, R.; Nyyssonen, K.; Palinski, W.; Witztum, J.L. Auto antibody against oxidised LDL and progression of carotid atherosclerosis. Lancet 1992, 339, 883-887.

24. Vinson, J.A.; Jang, J.H.; Dabbagh, Y.A.; Serry, M.M.; Cai, S.H. Plant polyphenols exhibit lipoprotein-bound antioxidant activity using an in vitro oxidation model for heart disease. J. Agric. Food Chem. 1995, 43, 2798-2799.

25. Xu, X.; Gu, L.; Holden, J.; Haytowitz, D.B.; Gebhardt, S.E.; Beecher, G.; Prior, R.L. Development of a database for total antioxidant capacity in foods: A preliminary study. J. Food Compos. Anal. 2004, 17, 407-422.

26. Shrestha, S.; Park, J.H.; Lee, D.Y.; Cho, J.G.; Lee, D.G.; Cho, M.H.; Jeong, T.S.; Kang, H.C.; Baek, N.I. Inhibition of low density lipoprotein-oxidation, ACAT-1, and ACAT-2 by lignans from the bark of Machilus thunbergii. J. Appl. Biol. Chem. 2011, 54, 63-66.

27. Lee, D.Y.; Lee, M.H.; Jung, T.S.; Kwon, B.M.; Baek, N.I.; Rho, Y.D. Triterpenoid and lignan from the fruits of Cornus kousa inhibit the activities of PRL-3 and LDL oxidation. J. Korean Soc. Appl. Biol. Chem. 2010, 53, 97-100.

28. Bueqe, J.A.; Aust, S.D. Microsomal lipid peroxidation. Methods Enzymol. 1978, 52, 302-310.

(C) 2014 by the authors; licensee MDPI, Basel, Switzerland. This article is an open access article distributed under the terms and conditions of the Creative Commons Attribution license (http://creativecommons.org/licenses/by/3.0/). 